Type of the Paper (Article)

\title{
Microstructural characterization and mechanical properties of Roman Mortars for their Restoration Case of the Historic site of Volubilis (Morocco)
}

\author{
A. Ammari ${ }^{1}$, A. Dekayir ${ }^{2}$ and M.A. Dos-Bennani ${ }^{3}$ \\ 1 LMM, Dept. of physics, Mohammed V University,Rabat, Morocco; abdelmalek09@gmail.com \\ 2 Equipe Géotech, Dept. of geologie, BP 11201Zitoune Meknes, Morocco \\ 3 LPEE, Bassatine Meknes, Morocco \\ * Correspondence: abdelamlek09@gmail.com ; Tel.: (+212607156800)
}

\begin{abstract}
The objective of this study is to conduct a mineralogical and chemical characterization of the mortars Roman archaeological site of Volubilis to rebuild spare mortars for restoration. We take samples of mortar, broken tile palate garden, and pavement mosaic Falavius Germanus houses. The analysis by X-ray diffraction reveals the coarse mortar Flavius Germanus is made of quartz and calcite with feldspar and probably, mica and dolomite in small amounts. The binder end is formed calcite and quartz. However, the broken tile mortar is formed by coarse particles, clay base mixed with a binder phase dominated by calcite. These results allowed us to reformulate spare mortars for the restoration of damaged Roman mosaics. The mortars are made up by $63.6 \%$ of lime and $36.4 \%$ of sand(with $4.19 \%$ of large grain, $71,04 \%$ of coarse sand, $24.22 \%$, of fine sand and $0.55 \%$ fines parts).The performance of these mortars was tested by mechanical testing.
\end{abstract}

Keywords: Mortar mosaic; Volubilis; Characterization; mineralogical; Testing; Mechanical.

\section{Introduction}

Volubilis is one of Africa's most famous archaeological sites. It is located $30 \mathrm{~km}$ far from Meknes City . It contains religious, politic monuments, houses and baths that are mainly decorated with opus tessellatum type mosaics (Fig. 1). In spite of their exposition to weathering for a long time, some of these mosaics remain well conserved. In order to develop the conservation and restoration of these mosaics, a good knowledge of the nature and characteristics of initial rocks and mortars used to build these mosaics is very important. So this work aims to study the petrological, mineralogical and geochemical characteristics of materials used in the building of these mosaics. Roman mosaics [1-2-5] of Volubilis are precious works of leaders. Since its ranking on the list of UNESCO World Heritage in 1987 [3], this city continues to receive special attention. Roman artists have exploited the geological formations around the city for the construction and decoration of mosaics through different materials. [4] Building mortars, including those of the mosaics and the baths built pavements show very advanced states of deterioration related to phenomena of weathering and soil instability of the city. The purpose of this research is the proceed first to a mineralogical and chemical characterization of a mean particle size of mortar samples from the Roman mosaic (Flavius Germanus) and another from the Baths of Galliens. Then, there is the alternative of recreation mortars with similar characteristics to the former mortars studied. 


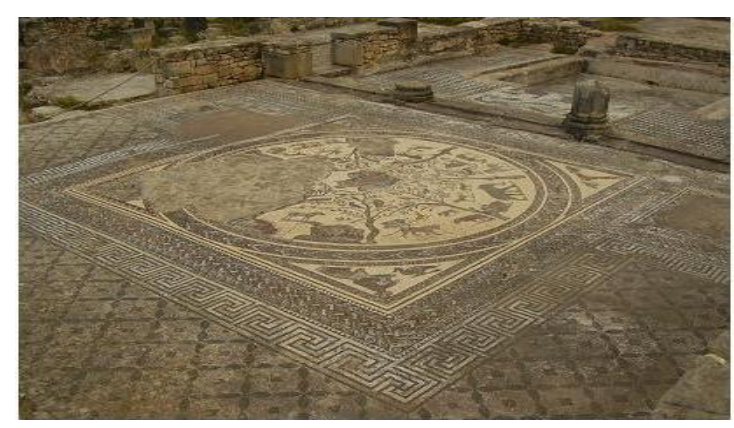

Fig.1: Roman mosaic

\section{Materials and Methods}

In the mosaic of Flavius Germanus (FG), mortar samples were collected in the nucleus layer (FGMG) and end binder (FGLF), while the mortar broken tile comes from basins gallien baths. The latter was used by the Romans in coating walls thermal baths. The mineralogy of the mortars is approximated by X-ray diffraction (X-ray powder diffraction). These samples were also analyzed by infrared spectroscopy to TF. Petrographic observations were made by optical microscopy on thin sections, and detailed scanning electron microscope coupled to a probe Microanalysis EDX [5].

\section{1- XRD technique}

The X-ray patterns of beach rock samples were recorded at room temperature by using X-ray diffractometer (D500, Siemens) having a curved graphite crystal diffracted monochromator, with a source of $\mathrm{CuKa}$ radiation and $\mathrm{NaI}(\mathrm{Tl})$ scintillation. Qualitative mineralogy of the beach rock samples is determined with the standard interpretation procedures of XRD.

\section{2- FT-IR technique}

The major and minor minerals are qualitatively determined by FT-IR technique. The KBr pellet technique (1:20) pellets were followed for the mineral analysis. For each samples are prepared and the spectra were taken in the mid region of $4000-400 \mathrm{~cm}^{-1}$.

\section{3 - Physical and mechanical properties}

The flexure strength of the specimens of mortars was determined on three specimens using the procedure described in the NF P14-306 standard [18]. The compressive strength of the four specimens obtained after the flexure strength test was measured with a hydraulic press with a ram speed of $0.025 \mathrm{~mm} / \mathrm{s}$ according to the NF P14-306 standard [18].

\subsection{1- Bending test}

The flexural strength (Rf) [12] (Fig.2) is calculated by the equation: $R f=(1.5 \times F f \times l) / b^{3}$

$\mathrm{Rf}=$ flexural strength,

$\mathrm{b}$ : the side of the square section of the prism, in millimeters

1: the distance between supports, in millimeters

In this case, the machine speed is considered the value of: $50 \mathrm{~N} / \mathrm{s}$

\subsection{2- Compressive test}

The compressive test (EN 1015-1011) is the test most widely used to characterize the quality of mortars. The resulting mechanical behavior is also seen as a fundamental characteristic of the material. This test is performed by applying a force or displacement to cylindrical or prismatic specimen. Compressive strength (Rc) [13] (Fig.3) is given by the following formula: $\quad$ RC=FC /1600 
Rc: is the compressive strength,

Fc: ic the maximum load at break, in Newtons,

1600: is the area of the plates and auxiliary plates $(40 \times 40)$ in $\mathrm{mm} 2$

With the speed of the machine is: $2400 \mathrm{~N} / \mathrm{s}$

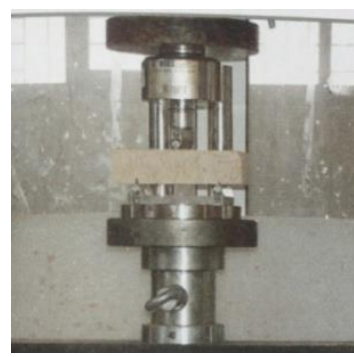

Fig.2: specimens bending test

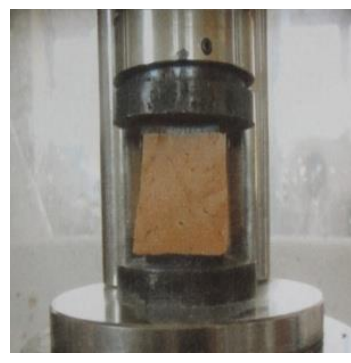

Fig. 3: Compressive test

\section{Results and discussion}

3.1. Mineralogy and chemical composition and granularity of Roman mortars

3.1.1. Mineralogy and chemical composition of mortars

3.1.1.1. Macroscopic and microscopic analysis of mortars

Broken tile mortar: it is a whitish gray mortar consisting of coarse elements of centimeter size based clay, mixed with lime to a very low percentage. Petrographic analysis shows this mortar formed elements of large size by $(\mathrm{cm})$ made from terracotta, cemented by a white paste containing lime (Fig.4).

Mortar mosaic (nucleus): is a mortar gray with white spots consisting of millimeter sized grains of sand, mixed with lime in a large percentage (Fig.4). This mortar (FGMG) shows the existence of quartz grains (a), shell fragments (b) and lithic sandstone fragments reused (c and d), cemented by calcite (Fig. 5 ).

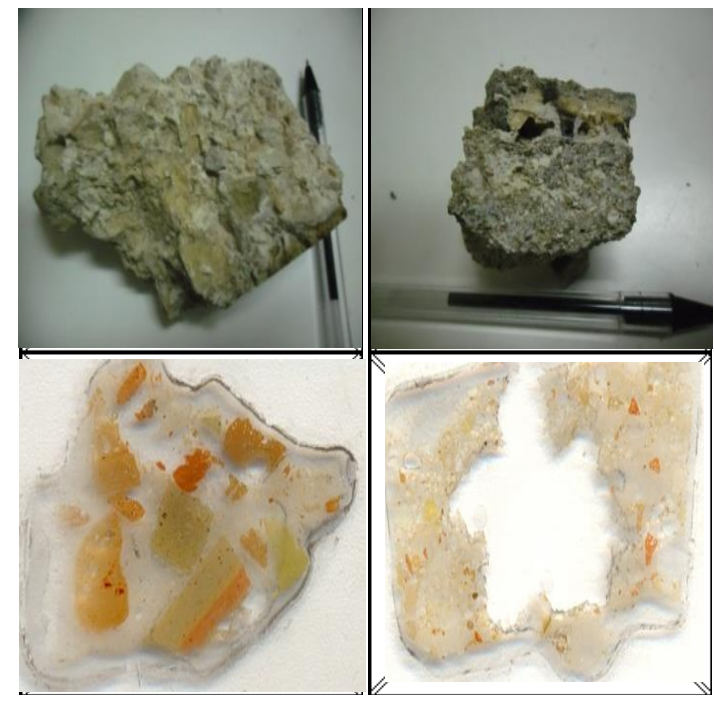

Figure 4. macroscopic views mortars

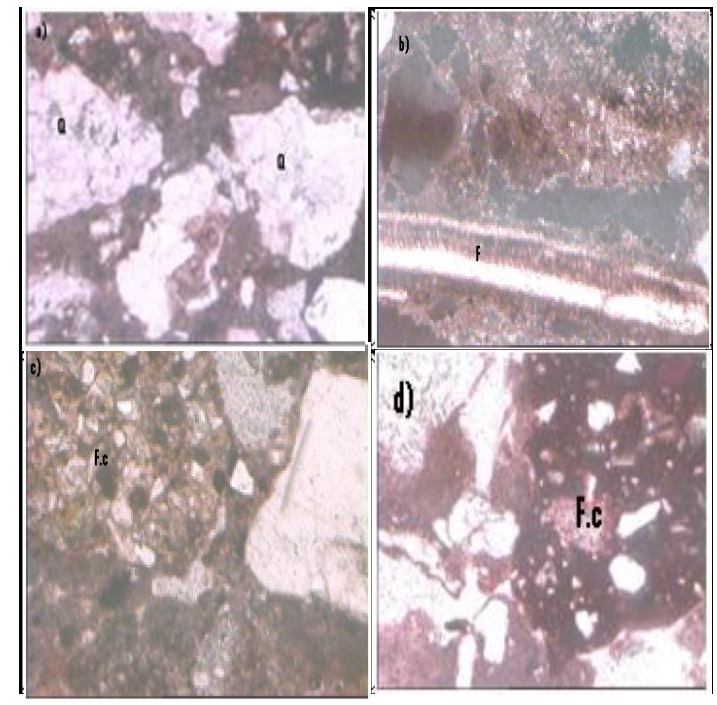

Figure 5. pictures of thin sections FG mortar

a) broken tile mortar (TG); b) mortar-type nucleus (FG) Q: quartz, Ca: calcite, F: fossil, Fc: shell fragments.

3.1.1.2. Mineralogy of the nucleus (FGMG) and binder (FGLF)

a-X-ray diffraction 
The X-ray diffraction and the analysis of the nucleus FGMG shows that it is a mortar consisting primarily of quartz and calcite, with traces of feldspar and probably mica and dolomite (FGMG,Fig.6a).

XRD shows that the binder of broken tile mortar is composed mainly of calcite (Fig. 7).

The following bands of vibrations, indexed to $1972.8217 ; 2098.1721 ; 2231.2363 ; 2281.3765 ; 2408.6553$, $2665.1414,3802.9368,3926.3586,838.8831 ; 1770.3326 \mathrm{~cm}-1$ are typical of calcite (Fig. 8).

b- Infrared spectroscopy (IRTF)

Infrared analysis (FGMG Fig. 6.b) of this mortar reveals bands of vibration of calcite (1797, 1427, 874, $712)$ and $\mathrm{cm}^{-1}$, quartz $(1034,778,796) \mathrm{cm}^{-1}$, kaolinite $(3695,3620,1034,796,767) \mathrm{cm}^{-1}$ and humid and fulvic acids and related to one root activity $(2982,2924,2913,2874) \mathrm{cm}^{-1}[5,9,10,14,15,16,17]$. While the analysis of the end binder (FGLF) shows spectra superimposed with those of coarse mortar (Fig. FGLF 6.a and 6.b FGLF) with very small quartz grains cemented by calcite. Unlike the coarse mortar, this binder is richer in quartz calcite as evidenced by the chemical analysis [5].
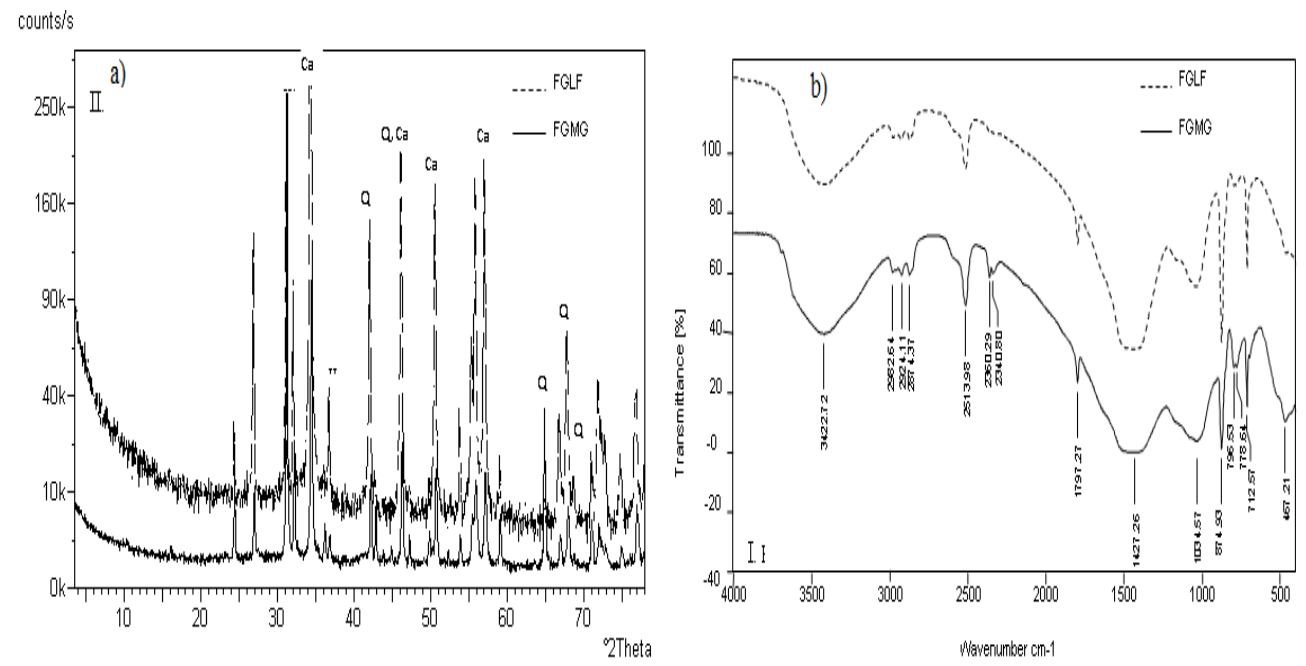

Figure 6. a) diffraction spectra of X-rays of the coarse mortar (FGMG) and binder end (FGLF) (Q: quartz; Ca: calcite; D: dolomite; F: feldspar M: Mica).

Figure 6. b) infrared spectra of: Coarse mortar (FGMG) and the end binder (FGLF) [5]

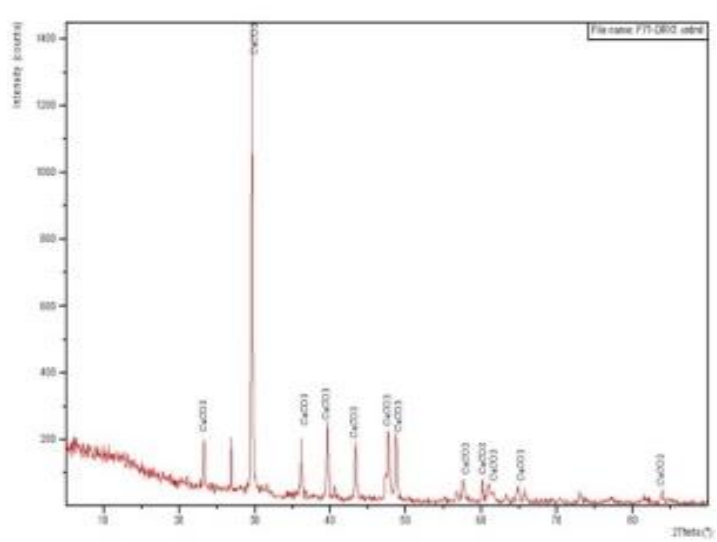

Figure.7: diffractogram binder mortar, broken tile

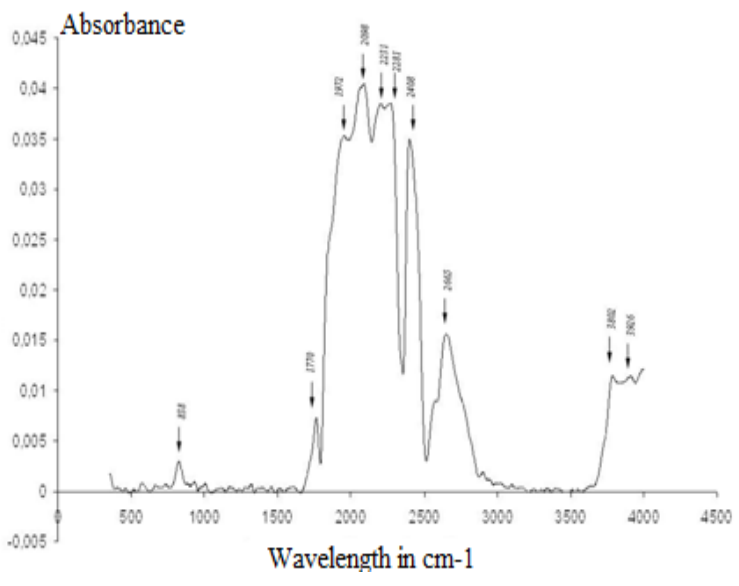

Figure.8: FTIR Analysis of the binder mortar broken tile 
c-Observations Scanning Electron Microscope (SEM)

The SEM analysis provides a detail view of the morphology of mortars. Indeed, the images obtained on the fine binder (Fig. 9) show the presence of quartz and abundance of calcite.

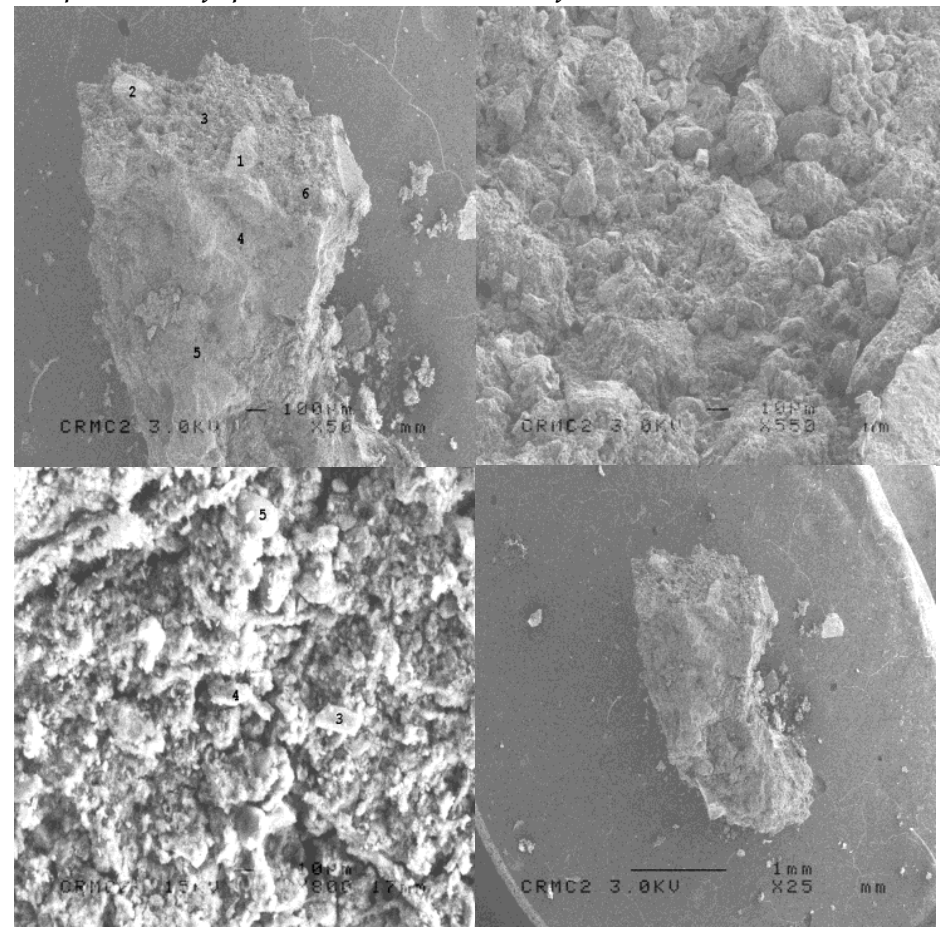

Figure 9. SEM pictures taken on linking end

\subsubsection{Chemical of the nucleus (FGMG) and binder (FGLF}

The chemical analyzes of the coarse mortar (FGMG) show a $\mathrm{SiO}_{2}$ content (35.63\%) high compared with that of the end binder (FGLF) due to the quartz concentration. Conversely, the binder end shows an enrichment in $\mathrm{CaO}$ linked to the abundance of carbonate matrix. The heat losses are to be bonded with the presence of water (Table 1).

Table 1. Chemical composition of the coarse and fine mortar binder used in the construction of a Roman mosaic [5]

\begin{tabular}{ccc}
\hline $\begin{array}{c}\text { Chemical } \\
\text { composition }\end{array}$ & FGMG & FGLF \\
\hline
\end{tabular}

\begin{tabular}{ccc} 
Minerals & $\begin{array}{c}\text { calcite, quartz, } \\
\text { feld., mica }\end{array}$ & calcite, quartz \\
$\mathrm{SiO}_{2}$ & $\mathbf{3 5 . 6 3}$ & $\mathbf{1 4 . 3 6}$ \\
$\mathrm{Al}_{2} \mathrm{O}_{3}$ & 3.21 & 2.39 \\
$\mathrm{Fe}_{2} \mathrm{O}_{3}$ & 1.19 & 0.85 \\
$\mathrm{MnO}$ & 0.03 & 0.02 \\
$\mathrm{CaO}$ & $\mathbf{3 0 . 2 9}$ & $\mathbf{4 4 . 3 8}$ \\
$\mathrm{MgO}$ & 0.56 & 0.35 \\
$\mathrm{Na}_{2} \mathrm{O}$ & 0.2 & 0.15 \\
$\mathrm{~K}_{2} \mathrm{O}$ & 0.93 & 0.5 \\
$\mathrm{TiO}_{2}$ & 0.16 & 0.1 \\
$\mathrm{P}_{2} \mathrm{O}_{5}$ & 0.41 & 0.55 \\
\hline
\end{tabular}




\begin{tabular}{ccc}
\hline LOI & 26.75 & 36.98 \\
Total & 99.36 & 100.63 \\
\hline
\end{tabular}

The matrix serves as a binder for both the coarse and fine mortar binder (Table.1) is essentially represented by calcite. It is the product of the carbonation of the lime used in the preparation of the mortar. Lime wasted with water and mixed with sand has the property of setting rapidly agglomerating inert particles such as quartz. The chemical reactions involved in the mortar and carbonating the binder are: [5]

Preparation of quicklime by burning limestone (between 900 and $100{ }^{\circ} \mathrm{C}$ ): $\mathrm{CaCO}_{3} \longrightarrow \mathrm{CaO}+\mathrm{CO}_{2}$; Preparation of slaked lime (portlandite) by mixing quicklime with water: $\mathrm{CaO}+\mathrm{H}_{2} \mathrm{O} \longrightarrow \mathrm{Ca}\left(\mathrm{OH}_{2}\right.$; Carbonation of the binder phase: $\mathrm{Ca}(\mathrm{OH})_{2}+\mathrm{CO}_{2} \quad \longrightarrow \mathrm{CaCO}_{3}+\mathrm{H}_{2} \mathrm{O}$.

\subsubsection{Texture and granularity of old mortars}

\subsubsection{Coarse mortar (FGMG)}

To achieve a particle size study of mortars, special treatment shall be effected before sifting. Indeed, the mortar is attacked $(15.02 \mathrm{~g})$ in $\mathrm{HCl}(1 / 5)$ to stop the excitement, indicating complete dissolution of carbonates in the sample. Then, the judgment sample is oven dried and then weighed.

The amount of limestone is dissolved: from 15.02 to $5.47=9.55 \mathrm{~g}$. The dry residue was sieved, the results are given in the following table (table.2).

Table.2: FG mortar Grain size

\begin{tabular}{ccccc}
\hline $\begin{array}{c}\text { Diameter } \\
(\mathbf{m m})\end{array}$ & Fraction & $\begin{array}{c}\text { Weight } \\
\text { refusal }(\mathbf{g})\end{array}$ & $\begin{array}{c}\text { Percentage } \\
\text { of refusal }\end{array}$ & $\begin{array}{c}\text { Cumulative } \\
\text { Percentage } \\
\mathbf{( \% )}\end{array}$ \\
\hline $\mathrm{CE}>2 \mathrm{~mm}$ & $\begin{array}{c}\text { Coarse } \\
\text { elements }\end{array}$ & 0.23 & 4.19 & 100 \\
$\mathrm{CS}: 2 \mathrm{~mm}-$ & Coarse sand & 3.90 & 71.04 & 95.81 \\
$200 \mu \mathrm{m}$ & Fine sand & 1.33 & 24.22 & 24.77 \\
$\mathrm{FS}: 200-50$ & & & \\
$\mu \mathrm{m}$ & Fine Fraction & 0.03 & 0.55 & 0.55 \\
\hline $\mathrm{FF}:<50 \mu \mathrm{m}$ & & & & \\
\hline
\end{tabular}

We note that the FG mortar skeleton is dominated by coarse sand at $71.04 \%$, followed by sand $(24.22 \%)$, and coarse elements to $4.19 \%$. The fine fraction is very low and on the order of $0.55 \%$.

\subsubsection{Calculation of the index Aggregation}

The figure below is derived from the results of Table 1 represents the cumulative percentage of the fractions according to particle size in $\mathrm{mm}$. The dissimilarity index calculated from the grading curve provides a quantitative sense of texture mortar studied. Calculating cluster index shows a value of the order of $61.77 \%$. 


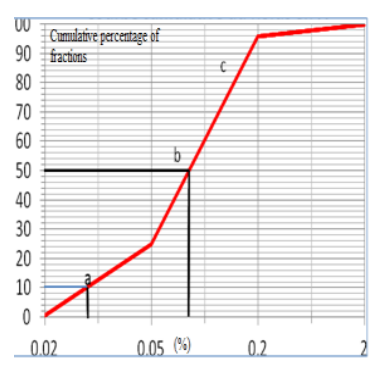

Figure.10: Refusal of the cumulative curve in $(\%)$

$$
\text { index Aggregation }=\frac{1}{a} \times \frac{(c-b)}{(b-a)}=61.77
$$

\subsubsection{The broken tile mortar}

After $\mathrm{HCl}$ attack, the skeleton is dominated by figurative elements based on terracotta of centimeter size, and its characteristics are summarized in the following table.3.

Table. 3 Characteristics of figurative elements of broken tile mortar

\begin{tabular}{cccc}
\hline & $\begin{array}{c}\text { Thickness } \\
(\mathbf{c m})\end{array}$ & Width $\mathbf{( c m )}$ & Length $\mathbf{( c m )}$ \\
\hline A & 1 & 3 at 2.7 & 3.5 at 3 \\
B & 0.9 & 1 at 1.4 & 2.5 at 2.1 \\
C & 0.5 & 2 at 2.1 & 2.5 at 2.1 \\
D & 0.3 at 1 & 0.8 at 2 & 4.3 at 5 \\
E & 0.3 at 0.5 & 2 at 1.5 & 1.4 at 2.8 \\
F & 1 at 1.3 & 0.4 at 1.5 & 1.5 at 2.3 \\
G & 0.3 at 1 & 0.5 at 1.8 & 1.5 at 2 \\
\hline
\end{tabular}

After three days of attacks $\mathrm{HCl} 1 / 5$ and after complete dissociation of the binder, we obtain the following particle size distribution

Table. 4 Percentage fractional component mortar broken tile
(\%)CE $>2 \mathrm{~mm}$
$(\%) C S: 2000-200 \mu \mathrm{m}$
(\%)FS : 200-50 $\mu \mathrm{m}$

\begin{tabular}{lll}
\hline 91.66 & 5.86 & 2.47 \\
\hline
\end{tabular}

We note that the mortar is dominated by coarse elements (91.66\%). Fig.11 shows the cumulative percentage of the fractions depending on the size of the particles in $\mathrm{mm}$, drawn from the results of Table 3.

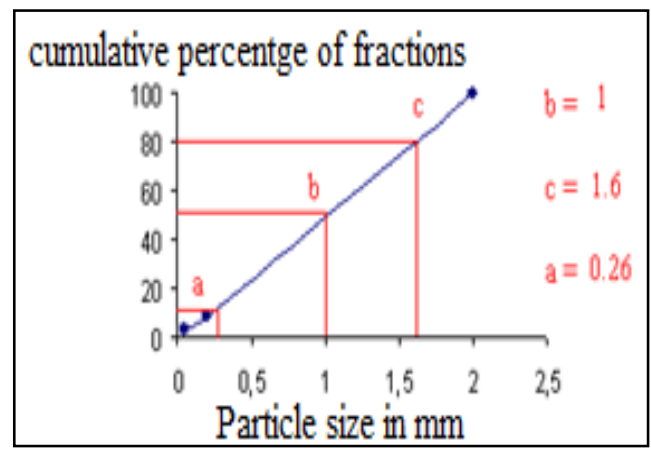

Figure.11: Particle size distribution of broken tile mortar 
The index of aggregation and 3.11 reflects the very coarse nature of this mortar.

\subsection{Preparation of spare mortar prisms for restoration}

The preparation of the mortar through a mixture of lime, water and sand, with very precise proportions. Indeed, the lime mixed with water is mixed and left for several hours. Once the mixture is ready, a well-defined amount of sand is added. Specimens of $4 \mathrm{~cm} \times 4 \mathrm{~cm} \times 16 \mathrm{~cm}$ were made with different percentages of sand and lime (table.4), the prisms are placed in the oven for $72 \mathrm{~h}$ at a temperature of $50^{\circ} \mathrm{C}$ for drying.

Table. 5: Percentages of sand and lime mortar used in prepared

\begin{tabular}{ccccc}
\hline mortars & $\begin{array}{c}\text { Percentage (\%) } \\
\text { of sand }\end{array}$ & lime (g) & sand (g) & water (ml) \\
\hline M1 & 20 & 400 & 100 & 800 \\
M2 & 30 & 350 & 150 & 700 \\
M3 & 40 & 300 & 200 & 600 \\
M4 & 50 & 250 & 250 & 500 \\
M5 & 66 & 170 & 330 & 300 \\
\hline
\end{tabular}

\subsubsection{Mineralogical sand, lime and prisms of mortars}

\subsubsection{XRD spectrum of lime}

The analysis by X-ray of the lime used in the preparation of mortars shows that it is formed mainly calcite and portlandite (Fig.12).

\subsubsection{XRD Sand Spectrum of Sand}

The analysis by X-ray of the sand used in the preparation of mortars shows that it is formed mainly of quartz, with traces of goethite, chlorite and probably mica and iron (Fig. 13).

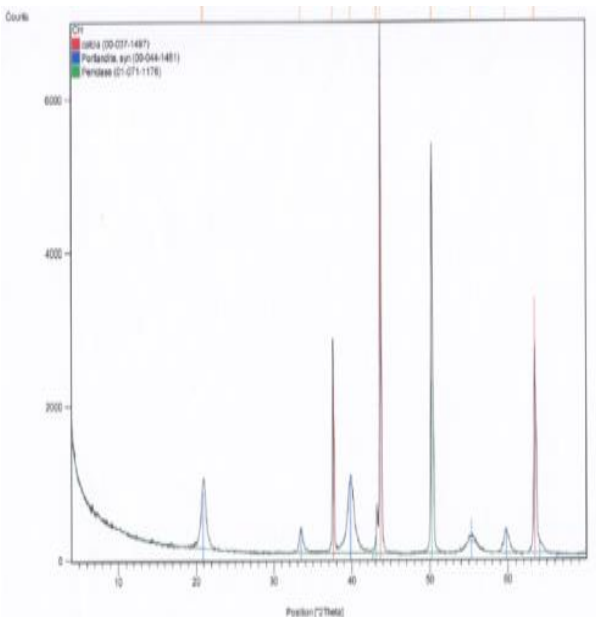

Fig. 12: diffraction spectrum of $X$ rays lime

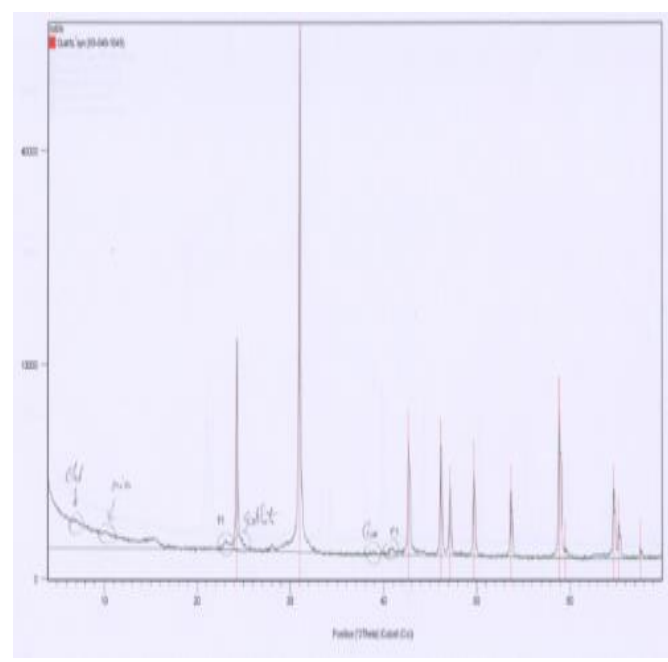

Fig. 13: diffraction spectrum of $X$ rays sand

\subsubsection{Spectrum mortar M1 (20\% sand)}

Diffraction analysis of X-ray mortar (M1) with a percentage of $20 \%$ sand and $80 \%$ of the lime shows that it is formed mainly of portlandite, quartz and calcite (Fig.14). 


\subsubsection{Mortar spectrum ( $66 \%$ sand)}

This diffraction analysis by X-ray mortar containing sand percentages (66\%) and lime (34\%), shows that it is formed mainly of quartz and portlandite and calcite (Fig.15).

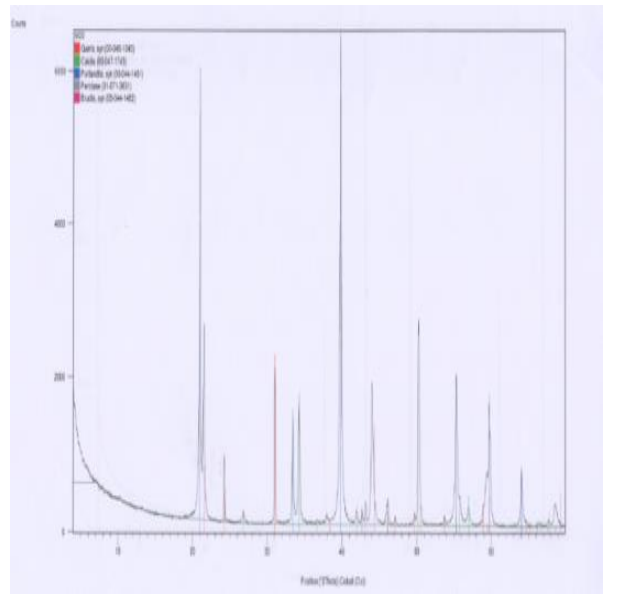

Fig. 14: Spectrum mortar (20\% sand)

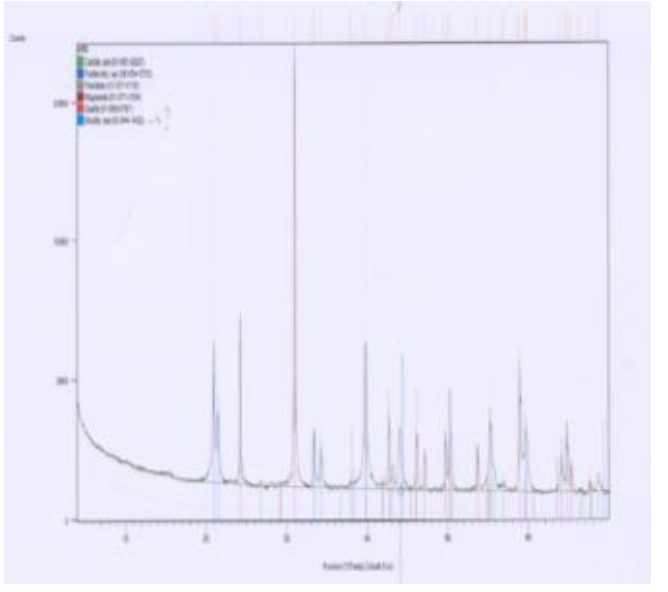

Fig. 15: Spectrum mortar (66\% sand)

3.2.2 Mortar Replacement

Table 6, below, gives the percentages of lime and sand used in the mortar spare and the drying period in the oven. We use this mortar the same refusal percentages of sand that are already found (tab.2).

Table.6: percentages of sand and lime mortar replacement

\begin{tabular}{cccccc}
$\begin{array}{c}\text { Mortar } \\
\text { Replacement }\end{array}$ & Lime (in g) & Sand (in g) & lime(\%) & sand(\%) & $\begin{array}{c}\text { Drying time } \\
\text { (in months) }\end{array}$ \\
\hline FGR-1 & 636 & 364 & 63.6 & 36.4 & 2 \\
FGR-2 & 636 & 364 & 63.6 & 36.4 & 3 \\
\hline
\end{tabular}

\subsubsection{The Mechanical tests on mortar spare FG-R}

The mechanical tests [11] aim to characterize the laws of behavior [8] materials (continuum mechanics). This law establishes the relationship between stress (pressure $=$ force $/$ area) and deformations (unit lengthening without dimensions). Table 7 summarizes the results of different mechanical tests (bending and compressive) conducted on the different parts of the mortar prisms.

Table. 7: bending and compressive values mortar MR: Replacement mortar.

\begin{tabular}{|c|c|c|c|c|c|c|}
\hline Specimens & $\begin{array}{l}\text { Drying } \\
\text { time }\end{array}$ & $\begin{array}{l}\text { Mass of } \\
\text { the } \\
\text { specimen } \\
\text { (g) }\end{array}$ & $\begin{array}{c}\text { Flexural } \\
\text { (Ff) in } \\
\text { KN }\end{array}$ & $\begin{array}{c}\text { Flexural } \\
\mathrm{MPa}\end{array}$ & $\begin{array}{l}\text { Compressive } \\
\text { (Fc) in KN }\end{array}$ & $\begin{array}{l}\text { Compressive } \\
\text { in } \mathrm{MPa}\end{array}$ \\
\hline \multirow{2}{*}{ MR-1-1 } & \multirow{2}{*}{2 months } & \multirow{2}{*}{279.3} & \multirow{2}{*}{0.15} & \multirow{2}{*}{0.35} & 1.45 & 0.91 \\
\hline & & & & & 1.63 & 1.02 \\
\hline \multirow{2}{*}{ MR-1-2 } & \multirow{2}{*}{2 months } & \multirow{2}{*}{278.7} & \multirow{2}{*}{0.16} & \multirow{2}{*}{0.37} & 1.22 & 0.76 \\
\hline & & & & & 1.73 & 1.08 \\
\hline \multirow{2}{*}{ MR-1-3 } & \multirow{2}{*}{2 months } & \multirow{2}{*}{259.8} & \multirow{2}{*}{0.12} & \multirow{2}{*}{0.28} & 1.49 & 0.93 \\
\hline & & & & & 1.59 & 0.99 \\
\hline \multirow{2}{*}{ MR2-1 } & \multirow{2}{*}{ 3months } & \multirow{2}{*}{310.4} & \multirow{2}{*}{0.32} & \multirow{2}{*}{0.75} & 4.68 & 2.92 \\
\hline & & & & & 3.27 & 2.04 \\
\hline
\end{tabular}


Table.7 shows that the compressive strength of the mortar increases with drying time, which gives us a big variation of the compressive strength from 2 months to 3 months of drying time, the value of compressive strength grows to reach $2.48 \mathrm{Mpa}$. The grains of mortar are also well coated by the lime. However, and because this increase depending on the particle size and mineralogical composition, this affects the economic investment in lime. In addition, the mineralogical results show that the clay of mortar is composed mainly of lime $\mathrm{CaO}$ and quartz $\mathrm{SiO}_{2}$, which promotes the stabilization of the clayey part by the reaction of lime and water. Hence, the grains of quartz of the mortar are cemented by the carbonation of the lime according to the following reactions $(1,2)$ :

$$
\begin{aligned}
& \mathrm{CaO}+\mathrm{H}_{2} \mathrm{O} \longrightarrow \mathrm{Ca}(\mathrm{OH})_{2} \text { (Portlandite), } \\
& \mathrm{Ca}(\mathrm{OH})_{2}+\mathrm{CO}_{2} \longrightarrow \mathrm{CaCO}_{3}+\mathrm{H}_{2} \mathrm{O},
\end{aligned}
$$

The quantitative formation of calcite in lime rich samples is the manifestation of the reaction of the hydrated lime with the atmospheric carbon dioxide. The dissolution of $\mathrm{CO} 2$ within the pastes increased with the increase of calcium affinity and consequently the carbonation reaction became predominant. Evidently, the excessive carbonation of the samples limited the formation of the cementitious hydrated compound. As a result of lime additions the compressive and bending strengths enhanced and water absorption declined (Table. 5). However, higher lime additions have partial detrimental effects on these properties. In all cases, the magnitudes of strengths are in the range of the required values for mortars. The improvement of the physical properties is attributed to the cementitious character of and to the development of minor amounts of calcite and portlandite.

\section{Conclusions}

This study allowed characterizing the mineralogy and Chemical of Roman mortar (the nucleus of the mosaic of broken tile and mortar Roman baths).

- For coarse mortar (FG), index Aggregation is very high (IA = 61.77), reflecting a fine particle size;

- For the broken tile mortar, yielded a very low index of aggregation (IA = 3.11), showing a coarse-grained character.

According to chemical analyzers, we found that the coarse and fine mortar matrix binder are represented mainly by calcite. The mineralogical analysis by X-ray diffraction of the coarse mortar and binder FG end shows that they consist mainly of quartz and calcite with different proportions (with traces of feldspar and probably mica and dolomite).

The replacement mortar (FG) is comprised of $63.6 \%$ lime and $36.4 \%$ sand $(4.19 \%$ of the coarse component, $71.04 \%$ coarse sand, fine sand $24.22 \%$, and $0.55 \%$ fine fraction).

Mechanical tests exerted on the mortar spare FG show that the prism (MR2) exhibits good compressive compared to other specimens because of a very slow setting.

Funding: This research received no external funding

\section{References}

1. F. Davidovits., Les Mortiers de pouzzolanes artificielles chez vitruve evolution et historique architecturale.,

Thèse de D.E.A, Université Paris X-Nanterre. (1992-1993).

2. R. Michel., Les scènes de métier dans la sculpture funéraire gallo-romaine., Gallia. Tome 36 fascicule 1 , (1978) 43-63. 
3. J-D. Mertz, M. Guiavarc, P. Pagnin., Comportement dilatométrique de mortiers de chaux pour la restauration.

4. N. DOMEDE., Thèse. L'Institut National des Sciences Appliquées de Toulouse. (2006).

5. A. Dekayir., M.Amouric., J.Olives., C.Parron., A. Nadiri., A. Chergui., M. A. El Hajraoui., Structure et caractérisation des matériaux utilisés dans la construction d'une mosaïque romaine de la cité de Volubilis (Maroc) C. R. Géoscience. 336 (2004) 1061-1070.

6. Pagliolico S.L., Ronchetti S., Turcato E.A., Bottino G., Gallo L.M., DePaolia R., Physicochemical and mineralogical characterization of earth for building in North West Italy., Applied Clay Science, 50 (2010) 439-454.

7. Y. Millogoa., M. Hajjaji., J.C. Morel., Physical properties, microstructure and mineralogy of termite mound material

considered as construction materials ., Applied Clay Science, 52 (2011) 160-164.

8. H. Bouabid., K. .Zine-dine., M. El Kortbi., S. Charif d'Ouazzane., O. Fassi-Fehri., Rev. Mar. Gén. Civ. 81 (1999) 16-19.

9. F. Gounya., F. Fouchal., P. Maillard., S. Rossignol., Construction and Building Materials. 36(2012) 188-195.

10. Y. Millogo., JC. Morel., Microstructural characterization and mechanical properties of cement stabilised adobes ., Materials and Structures, 45 (2012) 1311-1318.

11. A. Hakimi., N. Yamani., H. Ouissi., Non-linear behaviour of the compressed earth block by elasticity dammage coupling ., Matériaux et Construction. 29(1996) 600-608.

12. G. Azeredo., J.C. Morel., N. P. Barbosa., Journal of Urban and Environmental Engineering. 1(2007) $26-35$.

13. M. Olivier., A. Mesbah., Z. El Ghabi., L.C. Morel., Le Matériau Terre - L'Essai de Compactage Statique pour la Fabrication de Briques de Terre Compressée., Matériaux et constructions. 30 (1997) 515-517.

14. D.A. Silva., H.R. Wenk., P.J.M. Monteiro., Thermochimica Acta. 438 (2005) 35-40.

15. S. Andrejkovicová ., A.L. Velosa., E. Ferrazb., F. Rocha., Construction and Building Materials. 65 (2014) 132-139.

16. A. Ammari., K. Bouassria., A. Tayyibi., H. Bouabid., M. Cherraj., S. Charif D'ouazzane., M. Ibnoussina., J. Promoting the technique of grounding block compressed in the construction sector by improving its mechanical behavior ., Mater. Environ. Sci. 7 (10) (2016) 3532-3537.

17. A. Ammari, K. Bouassria, M. Cherraj, H. Bouabid, S. Charif D'ouazzane., Combined effect of mineralogy and granular texture on the technico-economic optimum of the adobe and compressed earth

blocks Case Studies in Construction Materials 7 (2017)

18. NF P 14-306 (1986) Blocs en béton cellulaire autoclave pour murs et cloisons. AFNOR, p 16 